\title{
What are the Environmental Determinants to Participate Among Stroke Survivors in Africa? a Scoping Review
}

\author{
Yohannes Awoke Assefa ( $\nabla$ 18yaa4@queensu.ca) \\ University of Gondar https://orcid.org/0000-0002-9557-866X \\ Zelalem Dessalegn Demeke \\ University of Gondar
}

\section{Research}

Keywords: stroke, participation, environmental factor, Africa

Posted Date: December 20th, 2021

DOI: https://doi.org/10.21203/rs.3.rs-1146161/v1

License: (a) This work is licensed under a Creative Commons Attribution 4.0 International License. Read Full License 


\section{Abstract \\ Background}

Stroke is the main cause of serious long-term disability worldwide, and it is the second commonest cause of death and a leading cause of adult disability. Two-thirds of stroke cases occur in low- and middle-income countries, which all African countries fall. In Africa, the incidence and survival rate of stroke is increasing. Various personal and environmental factors limit the participation of stroke survivors. As a result, in this review, we aimed to review the environmental factors that are influencing the participation of stroke survivors in Africa.

\section{Methods}

Five electronic databases were systematically searched in August 2021 and identified articles were screened by three authors based on predetermined criteria. We followed Arksey and O'Malley (2005) framework and the whole finding is reported using PRISMA-ScR. No date restrictions were imposed, and we included any type of papers including grey literature.

\section{Results}

584 articles were generated by our search, after removing duplicates, the title and abstract of 497 articles were screened. From the screening, 42 articles were selected for full article review from which 12 met the criteria to be included. We also manually searched and included one more article for the review.

\section{Conclusion}

Studies were mainly conducted in South Africa and assessed the adult population. We followed the International Classification of Functioning, Disability and Health (ICF) framework for the environmental determinants to present our findings. Products and Technology; Natural Environment and Human-Made Changes to Environment; and Services, Systems and Policies found to be a barrier for participation. Conversely, stroke survivors are getting good support from their immediate family and health professionals, which is found to be facilitating. This review could be used by policymakers to understand the environmental barriers that are hindering participation and help to improve the accessibility of the environment so stroke survivors can participate in the community.

\section{Introduction}

Stroke is the main cause of serious long-term disability worldwide (Pan, Sun, Okereke, Rexrode, \& Hu, 2011). It is the second commonest cause of death and a leading cause of adult disability (Bonita et al., 2004; Organization, 2008; The World Bank Annual Report 2003). Two-thirds of strokes occur in low-income and middle-income countries (Bonita et al., 2004). Also, over 87\% disability-adjusted life years (DALYs) from 
stroke was estimated to be in LMIC, which is about seven times the DALYs lost in high-income countries (Johnston, Mendis, \& Mathers, 2009). In Africa, the age-adjusted standardized annual stroke incidence is projected to be up to 316 per 100,000, with an age-adjusted standardized prevalence rate of up to 981 per 100, 000 people (Owolabi et al., 2015). Additionally, it was indicated that stroke in low-and middle-income countries continues rising (Feigin et al., 2014). Similarly, a study done in Africa also indicated an increase in stroke incidence and survival in Africa (Adeloye, 2014).

Depending on the severity of the stroke and the area of the brain affected, stroke causes temporary or permanent impairments in motor, cognitive, speech, perceptual, and sensory skills (Wolfe, 2000). These impairments, when combined with environmental barriers, can significantly impede a stroke survivor's ability to function and participate in life activities (Alguren, Lundgren-Nilsson, \& Sunnerhagen, 2009; Cawood, Visagie, \& Mji, 2016).

Participation is defined as 'involvement in a living situation' p. 14 in the International Classification of Functioning, Disability, and Health (ICF), and participation restrictions are described as problems an individual may experience in involvement in life situations' p. 14 ("International classification of functioning, disability, and health : ICF," 2001, p. 14). Studies show that stroke survivors have considerable participation restrictions, such as inability to return to previous occupations, decreased social interactions, and inability to participate in religious and leisure activities (Palstam, Sjödin, \& Sunnerhagen, 2019; Urimubenshi, 2015). Participation restriction has a significant negative impact on stroke survivors' health, quality of life, and well-being (Kwok, Pan, Lo, \& Song, 2011). Personal factors such as impairment level and disabilities, age, and most importantly environmental factors such as built environment, access, cost, social support influence stroke survivors' involvement in life situations or participation (Della Vecchia et al., 2021; Ezekiel et al., 2019).

Because the environmental factors that affect participation of stroke patients in African countries may differ from those identified in other continents, we conducted this scoping review with the goal of comprehensively examining and synthesizing the environmental factors that positively or negatively affect participation in life activities in African countries.

\section{Methods}

The aim of this study was, analyze available literature to identify the environmental factors that are positively or negatively determining participation of stroke survivors living in Africa. We used the framework suggested by Arksey and O'Malley (2005), revised by Levac, Colquhoun, and O'Brien (2010) to complete this review. We reported our research based on Preferred Reporting Items for Systematic Reviews and MetaAnalyses (PRISMA) Extension for Scoping Reviews (Tricco et al., 2018). Arksey and O'Malley (2005) suggest five stages namely: identifying the research question, identifying the relevant studies, study selection, charting the data, and collating, summarizing and reporting the results (Arksey \& O'Malley, 2005).

\section{Identifying the research question}


Our research question was, "What are the environmental determinants for participation in stroke survivors who live in Africa?"

\section{Identifying relevant studies}

We searched CINHAL, PubMed, Medline, and EMBASE. We also conducted a manual search on google scholar. We searched the databases from inception to August 2021 so as to include all relevant available literature. We used the following keywords and subject heads, "Participation or engagement or involvement or participate AND Challenges or barriers or difficulties or limitations or obstacles AND Stroke or cva or cerebrovascular accident or hemiplegia or hemiparesis or poststroke or post-stroke or stroke survival AND Africa or sub saharan africa or african countries or Algeria or Angola or Benin or Botswana or Burkina Faso or Burundi or Cameroon or Cabo Verde or Central African Republic or Chad or Comoros or Congo or the Democratic Republic of Congo or Cote dlvoire or Djibouti or Equatorial Guinea or Egypt or Eritrea or Ethiopia or Gabon or Gambia or Ghana or Guinea or Guinea-Bissau or Kenya or Lesotho or Liberia or Libya or Madagascar or Malawi or Mali or Mauritania or Mauritius or Morocco or Mozambique or Namibia or Niger or Nigeria or Rwanda or Senegal or Seychelles or Sierra Leone or Somalia or South Africa or Sudan or Swaziland or Tanzania or Togo or Tunisia or Uganda or Zambia or Zimbabwe."

\section{Study selection}

We exported the endnote citation to Covidence and carryout the screening on Covidence. Two Authors (Y.A and Z.D) screened titles and abstracts first, then screened full articles. Conflicts were discussed between the two authors until consensus was reached.

Figure 1 shows the PRISMA diagram of the process used in paper selection. Papers were reviewed using predetermined criteria:

- Articles only in English

- All style literature including grey literature to maximise and broaden the scope of literature found

- Articles conducted in Africa

- Articles assess the environmental determinants on stroke survivors

- All age group population who survived stoke, not TIA

\section{Results}

A total of 13 papers met the eligibility criteria and were included in the present scoping review. Table 1 (Additional file) summarizes the papers. Majority of the paper were conducted in South Africa. We used the 
ICF framework ("International classification of functioning, disability, and health : ICF," 2001) to thematize and present the review. ICF framework, under the environmental factors, comprises Products and Technology, Natural Environment and Human-Made Changes to Environment, Support and Relationships, Attitudes, and Services, Systems and Policies ("International classification of functioning, disability, and health : ICF," 2001) 
Table 1

Study characteristics of all included studies

\begin{tabular}{|c|c|c|c|c|c|c|}
\hline & Author(s) & $\begin{array}{l}\text { year of } \\
\text { publication }\end{array}$ & $\begin{array}{l}\text { study } \\
\text { location }\end{array}$ & $\begin{array}{l}\text { Study } \\
\text { populations }\end{array}$ & $\begin{array}{l}\text { Aims of the } \\
\text { study }\end{array}$ & Methodology \\
\hline 1. & $\begin{array}{l}\text { (Cawood \& } \\
\text { Visagie, } \\
\text { 2015) }\end{array}$ & 2015 & $\begin{array}{l}\text { South } \\
\text { Africa }\end{array}$ & $\begin{array}{l}\text { Adult stroke } \\
\text { survivors }\end{array}$ & $\begin{array}{l}\text { To determine } \\
\text { environmental } \\
\text { barriers and } \\
\text { facilitators to } \\
\text { participation } \\
\text { experienced } \\
\text { by a group of } \\
\text { stroke } \\
\text { survivors in the } \\
\text { Western Cape } \\
\text { province of } \\
\text { South Africa. }\end{array}$ & Mixed method \\
\hline 2. & $\begin{array}{l}\text { (Amosun, } \\
\text { Nyante, \& } \\
\text { Wiredu, } \\
\text { 2013) }\end{array}$ & 2013 & Ghana & $\begin{array}{l}\text { Adult stroke } \\
\text { survivors }\end{array}$ & $\begin{array}{l}\text { To assess the } \\
\text { perceived and } \\
\text { experienced } \\
\text { restrictions in } \\
\text { participation } \\
\text { and autonomy } \\
\text { among adult } \\
\text { stroke } \\
\text { survivors in } \\
\text { Ghana }\end{array}$ & Mixed method \\
\hline 3. & $\begin{array}{l}\text { (Mudzi, } \\
\text { Stewart, \& } \\
\text { Musenge, } \\
\text { 2013) }\end{array}$ & 2013 & $\begin{array}{l}\text { South } \\
\text { Africa }\end{array}$ & $\begin{array}{l}\text { Adult stroke } \\
\text { survivors } \\
\text { admitted to } \\
\text { hospital for } \\
\text { ischaemic } \\
\text { stroke }\end{array}$ & $\begin{array}{l}\text { The aim of this } \\
\text { study was to } \\
\text { establish the } \\
\text { level of } \\
\text { community } \\
\text { participation } \\
\text { of patients at } \\
12 \text { months } \\
\text { post-stroke } \\
\text { and the } \\
\text { associated } \\
\text { factors } \\
\text { impacting on } \\
\text { that } \\
\text { participation. }\end{array}$ & Mixed method \\
\hline 4. & $\begin{array}{l}\text { (Vincent- } \\
\text { Onabajo et } \\
\text { al., 2016) }\end{array}$ & 2016 & Nigeria & $\begin{array}{l}\text { Adult stroke } \\
\text { survivors }\end{array}$ & $\begin{array}{l}\text { To investigate } \\
\text { the impact of } \\
\text { social support } \\
\text { on } \\
\text { participation } \\
\text { of stroke } \\
\text { survivors in } \\
\text { Nigeria. }\end{array}$ & Quantitative \\
\hline
\end{tabular}




\begin{tabular}{|c|c|c|c|c|c|c|}
\hline & Author(s) & $\begin{array}{l}\text { year of } \\
\text { publication }\end{array}$ & $\begin{array}{l}\text { study } \\
\text { location }\end{array}$ & $\begin{array}{l}\text { Study } \\
\text { populations }\end{array}$ & $\begin{array}{l}\text { Aims of the } \\
\text { study }\end{array}$ & Methodology \\
\hline 5. & $\begin{array}{l}\text { (Maleka, } \\
\text { Stewart, \& } \\
\text { Hale, 2012) }\end{array}$ & 2012 & $\begin{array}{l}\text { South } \\
\text { Africa }\end{array}$ & $\begin{array}{l}\text { Adult stroke } \\
\text { survivors }\end{array}$ & $\begin{array}{l}\text { The aim of this } \\
\text { study was to } \\
\text { establish the } \\
\text { experience of } \\
\text { people living } \\
\text { with stroke in } \\
\text { low } \\
\text { socioeconomic } \\
\text { urban and } \\
\text { rural areas of } \\
\text { South Africa. }\end{array}$ & Qualitative study \\
\hline 6. & $\begin{array}{l}\text { (Anthea } \\
\text { Rhoda, } \\
\text { Cunningham, } \\
\text { Azaria, \& } \\
\text { Urimubenshi, } \\
\text { 2015) }\end{array}$ & 2015 & $\begin{array}{l}\text { South } \\
\text { Africa }\end{array}$ & $\begin{array}{l}\text { Adult stroke } \\
\text { survivors }\end{array}$ & $\begin{array}{l}\text { The aim of this } \\
\text { paper is to } \\
\text { present the } \\
\text { provision of in- } \\
\text { patient stroke } \\
\text { rehabilitation. } \\
\text { In addition the } \\
\text { challenges } \\
\text { experienced by } \\
\text { the individuals } \\
\text { with } \\
\text { participation } \\
\text { post discharge } \\
\text { are also } \\
\text { presented. }\end{array}$ & Mixed method \\
\hline 7. & $\begin{array}{l}\text { (Elloker, } \\
\text { Rhoda, } \\
\text { Arowoiya, \& } \\
\text { Lawal, 2019) }\end{array}$ & 2019 & $\begin{array}{l}\text { South } \\
\text { Africa }\end{array}$ & $\begin{array}{l}\text { Adult stroke } \\
\text { survivors }\end{array}$ & $\begin{array}{l}\text { The aim of this } \\
\text { study is to } \\
\text { investigate the } \\
\text { factors } \\
\text { influencing } \\
\text { community } \\
\text { participation } \\
\text { among } \\
\text { community- } \\
\text { dwelling stroke } \\
\text { survivors in the } \\
\text { Western Cape, } \\
\text { South Africa. }\end{array}$ & $\begin{array}{l}\text { Quantitative } \\
\text { method }\end{array}$ \\
\hline 8. & $\begin{array}{l}\text { (Arowoiya, } \\
\text { 2014) }\end{array}$ & 2014 & $\begin{array}{l}\text { South } \\
\text { Africa }\end{array}$ & $\begin{array}{l}\text { Adult stroke } \\
\text { patients }\end{array}$ & $\begin{array}{l}\text { The aim of this } \\
\text { study was to } \\
\text { determine and } \\
\text { explore the } \\
\text { participation } \\
\text { restrictions } \\
\text { experienced by } \\
\text { stroke } \\
\text { patients. }\end{array}$ & Mixed methods \\
\hline
\end{tabular}




\begin{tabular}{|c|c|c|c|c|c|c|}
\hline & Author(s) & $\begin{array}{l}\text { year of } \\
\text { publication }\end{array}$ & $\begin{array}{l}\text { study } \\
\text { location }\end{array}$ & $\begin{array}{l}\text { Study } \\
\text { populations }\end{array}$ & $\begin{array}{l}\text { Aims of the } \\
\text { study }\end{array}$ & Methodology \\
\hline 9. & $\begin{array}{l}\text { (Elloker, } \\
\text { 2016) }\end{array}$ & 2015 & $\begin{array}{l}\text { South } \\
\text { Africa }\end{array}$ & $\begin{array}{l}\text { Adult stroke } \\
\text { patients }\end{array}$ & $\begin{array}{l}\text { The aim of this } \\
\text { study is to } \\
\text { determine } \\
\text { social support } \\
\text { and } \\
\text { participation } \\
\text { restrictions in } \\
\text { patients with } \\
\text { stroke living in } \\
\text { selected areas } \\
\text { in the Western } \\
\text { Cape. }\end{array}$ & $\begin{array}{l}\text { Quantitative } \\
\text { method }\end{array}$ \\
\hline 10. & $\begin{array}{l}\text { (Ekechukwu, } \\
\text { Olaleye, \& } \\
\text { Hamzat, } \\
\text { 2017) }\end{array}$ & 2017 & Nigeria & $\begin{array}{l}\text { Adult stroke } \\
\text { patients }\end{array}$ & $\begin{array}{l}\text { This study } \\
\text { aims to } \\
\text { investigate the } \\
\text { clinical and } \\
\text { psychosocial } \\
\text { predictors of } \\
\text { CR among } \\
\text { stroke } \\
\text { survivors three } \\
\text { months post } \\
\text { in-hospital } \\
\text { discharge. }\end{array}$ & $\begin{array}{l}\text { Qualitative method } \\
\text { (exploratory study) }\end{array}$ \\
\hline 11. & $\begin{array}{l}\text { (Urimubenshi, } \\
\text { 2015) }\end{array}$ & 2015 & Rwanda & $\begin{array}{l}\text { stroke } \\
\text { patients }\end{array}$ & $\begin{array}{l}\text { To explore the } \\
\text { activity } \\
\text { limitations and } \\
\text { participation } \\
\text { restrictions } \\
\text { experienced by } \\
\text { people with } \\
\text { stroke in } \\
\text { Musanze } \\
\text { district in } \\
\text { Rwanda. }\end{array}$ & $\begin{array}{l}\text { Qualitative method } \\
\text { (phenomenological) }\end{array}$ \\
\hline 12. & $\begin{array}{l}\text { (Soeker \& } \\
\text { Olaoye, } \\
\text { 2017) }\end{array}$ & 2017 & Nigeria & $\begin{array}{l}\text { stroke } \\
\text { survivors }\end{array}$ & $\begin{array}{l}\text { The study was } \\
\text { aimed at } \\
\text { exploring and } \\
\text { describing the } \\
\text { experiences of } \\
\text { rehabilitated } \\
\text { stroke } \\
\text { survivors and } \\
\text { perceptions of } \\
\text { stakeholders } \\
\text { about stroke } \\
\text { survivors } \\
\text { returning to } \\
\text { Work in South- } \\
\text { West Nigeria. }\end{array}$ & Qualitative method \\
\hline
\end{tabular}




\begin{tabular}{|llllll|}
\hline Author(s) & $\begin{array}{l}\text { year of } \\
\text { publication }\end{array}$ & $\begin{array}{l}\text { study } \\
\text { location }\end{array}$ & $\begin{array}{l}\text { Study } \\
\text { populations }\end{array}$ & $\begin{array}{l}\text { Aims of the } \\
\text { study }\end{array}$ & Methodology \\
\hline 13. $\begin{array}{l}\text { (A Rhoda, } \\
\text { 2012) }\end{array}$ & 2012 & $\begin{array}{l}\text { South } \\
\text { Africa }\end{array}$ & $\begin{array}{l}\text { Stroke } \\
\text { survivors }\end{array}$ & $\begin{array}{l}\text { the aim of the } \\
\text { study was } \\
\text { therefore to } \\
\text { explore the } \\
\text { activity } \\
\text { limitations and } \\
\text { participation } \\
\text { restrictions } \\
\text { experienced by } \\
\text { patients with a } \\
\text { stroke. }\end{array}$ \\
\hline
\end{tabular}

\section{Product and Technology}

Product and technology is defined by WHO as "any product, instrument, equipment or technology adapted or specially designed for improving the functioning of a disabled person" ("International classification of functioning, disability, and health : ICF," 2001, p. 180).

Five studies mentioned how products and technologies facilitate or barriers participation of people living with stroke. In the study, Cawood and Visagie (2015) conducted, 77\% of participants identified products and technology as a barrier. Difficulty to use transport appeared frequently as a barrier (Arowoiya, 2014; Cawood \& Visagie, 2015; Elloker, 2016; Mudzi et al., 2013). In their study, Mudzi et al. (2013), revealed that $100 \%$ of stroke survivors mentioned transport services as mild to moderate barrier to participation. Transport created barrier to community participation and accessing services for $80 \%$ of participants (Cawood \& Visagie, 2015).

Additionally, it was stated people with stroke need to pay extra to use public transport if they could find a driver who is willing to take them (Arowoiya, 2014; Mudzi et al., 2013). Lack of assets such as money also appeared among stroke survivors as a barrier to participate in social activities (Cawood and Visagie (2015). Cawood and Visagie (2015) stated that stroke survivors were not able to afford phone service. Not only this, but they were also unable to pay for assistive devices (Cawood \& Visagie, 2015). In the same vein, Access to and utilization of assistive devices was also found low in the studies (Arowoiya, 2014; Cawood \& Visagie, 2015). Cawood and Visagie (2015) stated other than mobility devices people living with stroke struggle to get assistive devices such as bath transfer, grab bars and Ankle foot orthosis. Moreover, they also struggle to use a toilet that is not modified to accommodate their need (Arowoiya, 2014). A Rhoda (2012) mentioned how stroke survivors can benefit from and are dependent on their walking devices.

Also, due to inaccessibility of the public transport, people with stroke need to have someone who can assist to carry and put them on wheelchair as well as in and out of the car in a way that indiginify the people (Arowoiya, 2014). 


\section{Natural Environment and Human-Made Changes to Environment}

Regarding Natural Environment and Human-Made Changes to Environment, nine articles met the inclusion criteria (Amosun et al., 2013; Arowoiya, 2014; Cawood \& Visagie, 2015; Elloker, 2016; Elloker et al., 2019; Maleka et al., 2012; Anthea Rhoda et al., 2015; Soeker \& Olaoye, 2017; Urimubenshi, 2015). Almost all studies concluded the natural and human-made environment is inaccessible and creates barrier for participation. Amosun et al. (2013) stated in their article that environmental barriers led to self-imposed restriction as stroke survivors would prefer to stay at home than go out and experience the environmental difficulty. Elloker et al. (2019) also asserted how mobility, in a fully accessible environment facilitates participation.

Inaccessibility of the environment also hindered people living with stroke from participating in rehabilitation therapy (Anthea Rhoda et al., 2015; Soeker \& Olaoye, 2017). This further complicated their condition and deteriorate their recovery and ability to participate. Soeker and Olaoye (2017) concluded home to clinic distance was a major factor not to adhere to therapy. On the other hand, some people changed their home address to live near hospitals where they get therapy (Urimubenshi, 2015) This led them to lose their previous social contact (Urimubenshi, 2015).

We also found in the articles that the home and the surrounding environment were inaccessible and a barrier to participation (Amosun et al., 2013; Arowoiya, 2014; Cawood \& Visagie, 2015; Maleka et al., 2012; Anthea Rhoda et al., 2015; Urimubenshi, 2015). Cawood and Visagie (2015) found in their study that $65 \%$ of public buildings were inaccessible. Walking or pushing a wheelchair on sandy and uneven pavements creates huge inaccessibility and result in hindered social participation (Cawood \& Visagie, 2015). Stairs to get in and out of their home, and the sandy and the uneven way in the neighbourhood make mobility with or without a wheelchair very difficult (Cawood \& Visagie, 2015; Urimubenshi, 2015). Arowoiya (2014) also asserted that among their study participants about $21 \%$ face severe difficulty to deal with the physical environmental barriers in their society. Anthea Rhoda et al. (2015) also found stones on the way, stairs and uneven grounds create a barrier to use wheelchair and hinder social participation of stroke survivors. The home environment was also inaccessible. Maleka et al. (2012) revealed that the homes where stroke survivors were living in small, and cluttered homes.

\section{Support and Relationships}

Eleven articles out of thirteen discussed support and relationships in stroke survivors. We found a contradicting result. Five articles (Cawood \& Visagie, 2015; Ekechukwu et al., 2017; A Rhoda, 2012; Soeker \& Olaoye, 2017; Vincent-Onabajo et al., 2016) discussed people living with stroke are getting positive social support that is facilitating participation. Conversely, five articles (Amosun et al., 2013; Arowoiya, 2014; Elloker, 2016; Anthea Rhoda et al., 2015; Urimubenshi, 2015) stated that social support and relationships were low and eventually negatively affecting stroke survivors. 
Mudzi et al. (2013) assessed the support and relationship in terms of immediate family; personal care providers friends; acquaintances, peers, colleagues, neighbours, and community members. They found immediate family and personal care providers were supportive and facilitators to participation (Mudzi et al., 2013). However, stroke patients saw the support from their friends as a barrier to social participation (Mudzi et al., 2013). Cawood and Visagie (2015) also found that majority (88\%) of stroke survivors' immediate families were supportive. Stroke survivors need social support and assistance for ADL and IADL activities from family members (A Rhoda, 2012). By the same token, they also get positive support in the workplace to resume their previous work (Soeker \& Olaoye, 2017). Ekechukwu et al. (2017), while assessing the clinical and psychosocial predictors of community reintegration of stroke survivors, revealed stroke survivors who received good social support were better in reintegrating into the community. Vincent-Onabajo et al. (2016) also asserted that a high level of social support is associated with better social participation and economic self-sufficiency.

However, we also understood from the articles that as time passes the support and relationship diminishes (Anthea Rhoda et al., 2015). In the study done in Rwanda, to assess activity limitations and participation restrictions, Urimubenshi (2015) revealed that the social interaction of stroke survivors decreased from time to time. One reason stated was people with stroke changed to more accessible and near to hospital residency (Urimubenshi, 2015). Others also could not maintain their relationship with friends due to financial restrain (Arowoiya, 2014). Elloker (2016) assessed the social support and participation restrictions in patients living with stroke in South Africa. He revealed that nearly $90 \%$ of stroke survivors have low social support (Elloker, 2016). Amosun et al. (2013) discussed how low family support leads to family-imposed participation restrictions. Similarly, Anthea Rhoda et al. (2015) also discussed how lack of support barriers stroke survivors from participation. For people who were receiving support, the majority indicated they are very satisfied with the support given (Elloker, 2016). Based on the result, Elloker (2016) concluded that despite the low level of social support, stroke survivors valued the support they received.

\section{Attitudes}

Four articles discuss how the attitude towards stroke survivors is positively or negatively determining participation (Amosun et al., 2013; Arowoiya, 2014; Cawood \& Visagie, 2015; Mudzi et al., 2013).

Cawood and Visagie (2015) found in their study that majority of immediate families have positive attitudes towards stroke survivors. Additionally, the attitude of health professionals was a facilitator for participation (Cawood \& Visagie, 2015). However, the societal attitude was found negative and created a barrier for participation (Arowoiya, 2014; Cawood \& Visagie, 2015). Mudzi et al. (2013) also revealed in their study that majority of friends' attitudes were a barrier for stroke survivors to participate in their community.

We also understood from the articles that people see the stroke survivor as pity and support from the sense of duty (Arowoiya, 2014; Cawood \& Visagie, 2015). The negative attitude does not always come from another person, but stroke survivors have also a perceived negative attitude that hinders participation (Amosun et al., 2013). Amosun et al. (2013) concluded that stroke survivors experienced both self and enacted stigma. 


\section{Services, Systems and Policies}

We could not find much about services, systems and policies and how it is affecting the participation of stroke survivors. Three articles (Cawood \& Visagie, 2015; Mudzi et al., 2013; Soeker \& Olaoye, 2017) discussed services, systems and policies regarding participation. Results from the articles showed services, systems and policies are barriers to participation for stroke survivors. For example, Cawood and Visagie (2015) revealed that nearly half of their study's participants indicated that they did not receive assistance from associations or organizations. Cawood and Visagie (2015) and Mudzi et al. (2013) presented that housing services were a barrier. Stroke survivors experienced difficulties to get government subsidised houses (Cawood \& Visagie, 2015). Housing policies were also a barrier (Mudzi et al., 2013). Additionally, the paperwork to process disability grants took too long which led the stroke survivors to financial strain (Cawood \& Visagie, 2015). In another study, Soeker and Olaoye (2017) indicated stroke survivors struggle from financial constraints that led them to opt-out from therapy. This indicates that there was no or minimum support to help them continue their therapy.

\section{Discussion}

Evidence has shown that personal factors such as level of function, motor activity, cognitive ability and executive function determined level of participation (Adamit et al., 2015; D'Alisa, Baudo, Mauro, \& Miscio, 2005; Desrosiers et al., 2006). In this review, we particularly examined the environmental determinates of participation among stroke survivors. We identified 584 papers and reviewed 13 papers to understand the environmental determinants for participation among stroke survivors living in Africa. We used the ICF framework ("International classification of functioning, disability, and health : ICF," 2001) to thematize and present our findings. Every style of paper including grey literature were included in the review, and we did not set a time limit to our search so we could include as many studies as we can. We presented our findings grouped under Products and Technology, Natural Environment and Human-Made Changes to Environment, Support and Relationships, Attitudes and Services, Systems and Policies.

Regarding product and technology, access to transport, service charge for transport and access to assistive devices appeared to be a barrier for participation for stroke survivors (Arowoiya, 2014; Cawood \& Visagie, 2015; Elloker, 2016; Mudzi et al., 2013; A Rhoda, 2012). Stroke survivors struggle to get accessible public transport, and even if they get they have to pay extra for the service (Arowoiya, 2014; Mudzi et al., 2013). Moreover, public transport cars are not accessible, and they have to find assistance to carry them and put them in the car, which indignified stroke survivors (Arowoiya, 2014). It was also evident from the studies that there is limited access to assistive devices that limit mobility in the community which eventually limits participation. The low provision and utilization of products and technologies, as it was evident from the literature, greatly hinders the participation of stroke survivors in life activities. This creates frustration to go out and participate in the community. Hence, people usually prefer to stay at home and avoid social participation. This indicates increasing accessible transport in the community could help to facilitate the participation of stroke survivors. 
The natural and human-made environment was also found inaccessible and barriers to participation. It is obvious that a fully accessible environment facilitates mobility, and participation (Elloker et al., 2019). Inaccessible environment hinders participation and led stroke survivors to self-imposed restrictions (Amosun et al., 2013). Inaccessibility hinders participation in therapy (Anthea Rhoda et al., 2015; Soeker \& Olaoye, 2017), which negatively affected the prognosis of their condition and further prevents them from participation. Based on the reviewed articles, the road in the neighbourhood of stroke survivors was full of obstacles, and far from hospitals (Cawood \& Visagie, 2015; Anthea Rhoda et al., 2015; Urimubenshi, 2015). Additionally, public buildings were also found inaccessible that people with mobility issues could not access (Cawood \& Visagie, 2015).

Most of the evidence, but also contradicting, were found regarding support and relationships. Eleven out of thirteen articles discussed how support and relationships are positively or negatively affecting participation among stroke patients in Africa. The articles (Cawood \& Visagie, 2015; Ekechukwu et al., 2017; Mudzi et al., 2013; A Rhoda, 2012; Soeker \& Olaoye, 2017; Vincent-Onabajo et al., 2016) asserted that stroke survivors are receiving good social support from immediate family, clinicians and coworkers. This facilitates their social participation. However, it was also evident from the articles that the support diminishes as time passes (Anthea Rhoda et al., 2015). The low social support from friends also appeared as a barrier to participation (Mudzi et al., 2013). From the results, one can conclude that professional support for the immediate family, including family and friends in the therapy so they can understand the condition and how to support, can benefit to increase stroke survivors participation.

Similarly, the attitude of immediate family and health professionals was found to be positive and facilitating (Cawood \& Visagie, 2015). However, the negative societal attitude barriers participation (Arowoiya, 2014; Cawood \& Visagie, 2015). Stroke survivors also had a negative attitude about themselves that cause self-induced participation restriction (Amosun et al., 2013).

There was a scarcity of evidence showing the effect of services, systems and policies on participation. The existing evidence, however, showed the services, systems and policies are barriers to participation (Cawood \& Visagie, 2015; Mudzi et al., 2013; Soeker \& Olaoye, 2017). There is limited assistance for stroke patients from government or nongovernment organizations (Cawood \& Visagie, 2015).

The limitations of this review were; we only included articles published in the English language. As a result, articles published in other languages were not included. Additionally, a methodological appraisal was also beyond the scope of this study. Hence, the absence of this can be considered as a limitation of the study.

\section{Conclusion}

Stroke is the main cause of serious long-term disability worldwide. Not only this, but evidence also showed it is increasing in Africa. Stroke limits participation. In this scoping review, we assessed how the environment, in Africa, is positively or negatively affecting participation among stroke patients. Studies were mainly conducted in South Africa and assessed the adult population. We followed the ICF framework for the environmental determinants to present our findings. Products and Technology, Natural Environment and 
Human-Made Changes to Environment, and Services, Systems and Policies found to be a barrier for stroke survivors to participate. Conversely, stroke survivors are getting good support from their immediate family and health professionals. The result of this review suggests that there is a gap in making the environment accessible, provision of assistive devices. This hugely decreases the participation of stroke survivors. Policy makers and other government and non-government organizations can use this review to understand and fill the gap. Additionally, health care providers and social workers can utilize the support and relationship stroke survivors may have to improve their participation.

\section{Abbreviations}

- DALYs - Disability-adjusted life years

- ICF - The International Classification of Functioning, Disability and Health

- PRISMA - Preferred Reporting Items for Systematic Reviews and Meta-Analyses

\section{Declarations}

\section{Acknowledgements}

Not applicable.

\section{Funding}

No funding was received for the study.

\section{Author information}

\section{Affiliations}

${ }^{1}$ University of Gondar, School of Medicin, Occupational Therapy department, Gondar, Ethiopia

\section{Contributions}

YAA and ZDD conceived and drafted the scoping review. The authors read and approved the final manuscript.

\section{Corresponding author}

Correspondence to Yohannes Awoke Assefa.

\section{Ethics declarations}

Not applicable.

\section{Consent for publication}

Not applicable. 


\section{Competing interests}

The authors declare that they have no competing interests.

\section{References}

1. Adamit, T., Maeir, A., Ben Assayag, E., Bornstein, N. M., Korczyn, A. D., \& Katz, N. (2015). Impact of firstever mild stroke on participation at 3 and 6 month post-event: the TABASCO study. Disability and Rehabilitation, 37(8), 667-673. doi:10.3109/09638288.2014.923523

2. Adeloye, D. (2014). An estimate of the incidence and prevalence of stroke in Africa: a systematic review and meta-analysis. PLOS ONE, 9(6), e100724.

3. Alguren, B., Lundgren-Nilsson, Å., \& Sunnerhagen, K. S. (2009). Facilitators and barriers of stroke survivors in the early post-stroke phase. Disability and Rehabilitation, 31(19), 1584-1591.

4. Amosun, S., Nyante, G., \& Wiredu, E. (2013). Perceived and experienced restrictions in participation and autonomy among adult survivors of stroke in Ghana. African health sciences, 13(1), 24-31.

5. Arksey, H., \& O'Malley, L. (2005). Scoping studies: towards a methodological framework. International journal of social research methodology, 8(1), 19-32.

6. Arowoiya, A. I. (2014). Participation restrictions of stroke patients living in the community at selected community health centres in the Metropole Districts in the Western Cape, South Africa.

7. Bonita, R., Mendis, S., Truelsen, T., Bogousslavsky, J., Toole, J., \& Yatsu, F. (2004). The Global Stroke Initiative. The Lancet Neurology, 3(7), 391-393. doi:https://doi.org/10.1016/S1474-4422(04)00800-2

8. Cawood, J., \& Visagie, S. (2015). Environmental factors influencing participation of stroke survivors in a Western Cape setting. African Journal of Disability, 4(1), 1-9.

9. Cawood, J., Visagie, S., \& Mji, G. (2016). Impact of post-stroke impairments on activities and participation as experienced by stroke survivors in a Western Cape setting. South African Journal of Occupational Therapy, 46, 10-15. Retrieved from http://www.scielo.org.za/scielo.php? script=sci_arttext\&pid=S2310-38332016000200003\&nrm=iso

10. D'Alisa, S., Baudo, S., Mauro, A., \& Miscio, G. (2005). How does stroke restrict participation in long-term post-stroke survivors? Acta Neurologica Scandinavica, 112(3), 157-162.

doi:https://doi.org/10.1111/j.1600-0404.2005.00466.x

11. Della Vecchia, C., Viprey, M., Haesebaert, J., Termoz, A., Giroudon, C., Dima, A., . . Schott, A.-M. (2021). Contextual determinants of participation after stroke: a systematic review of quantitative and qualitative studies. Disability and Rehabilitation, 43(13), 1786-1798.

12. Desrosiers, J., Rochette, A., Noreau, L., Bourbonnais, D., Bravo, G., \& Bourget, A. (2006). Long-term changes in participation after stroke. Topics in Stroke Rehabilitation, 13(4), 86-96.

13. Ekechukwu, N., Olaleye, O., \& Hamzat, T. (2017). Clinical and psychosocial predictors of community reintegration of stroke survivors three months post in-hospital discharge. Ethiopian journal of health sciences, 27(1), 27-34. 
14. Elloker, T. (2016). Social support and participation restrictions in patients living with stroke in the Western Cape, South Africa.

15. Elloker, T., Rhoda, A., Arowoiya, A., \& Lawal, I. U. (2019). Factors predicting community participation in patients living with stroke, in the Western Cape, South Africa. Disability and Rehabilitation, 41(22), 2640-2647.

16. Ezekiel, L., Collett, J., Mayo, N. E., Pang, L., Field, L., \& Dawes, H. (2019). Factors associated with participation in life situations for adults with stroke: A systematic review. Archives of Physical Medicine and Rehabilitation, 100(5), 945-955.

17. Feigin, V. L., Forouzanfar, M. H., Krishnamurthi, R., Mensah, G. A., Connor, M., Bennett, D. A., . . . Truelsen, T. (2014). Global and regional burden of stroke during 1990-2010: findings from the Global Burden of Disease Study 2010. The Lancet, 383(9913), 245-255.

18. . International classification of functioning, disability, and health : ICF. (2001): Version 1.0. Geneva : World Health Organization, [2001] @)2001. Retrieved from https://search.library.wisc.edu/catalog/999977181002121

19. Johnston, S. C., Mendis, S., \& Mathers, C. D. (2009). Global variation in stroke burden and mortality: estimates from monitoring, surveillance, and modelling. The Lancet Neurology, 8(4), 345-354. doi:https://doi.org/10.1016/S1474-4422(09)70023-7

20. Kwok, T., Pan, J.-H., Lo, R., \& Song, X. (2011). The influence of participation on health-related quality of life in stroke patients. Disability and Rehabilitation, 33(21-22), 1990-1996.

21. Levac, D., Colquhoun, H., \& O'Brien, K. K. (2010). Scoping studies: advancing the methodology. Implementation science, 5(1), 1-9.

22. Maleka, M., Stewart, A., \& Hale, L. (2012). The experience of living with stroke in low urban and rural socioeconomic areas of South Africa. South African Journal of Physiotherapy, 68(3), 25-29.

23. Mudzi, W., Stewart, A., \& Musenge, E. (2013). Community participation of patients 12 months poststroke in Johannesburg, South Africa. African Journal of Primary Health Care and Family Medicine, 5(1), 1-9.

24. Organization, W. H. (2008). The global burden of disease: 2004 update: World Health Organization.

25. Owolabi, M. O., Akarolo-Anthony, S., Akinyemi, R., Arnett, D., Gebregziabher, M., Jenkins, C., ... Members of the, H. A. C. (2015). The burden of stroke in Africa: a glance at the present and a glimpse into the future. Cardiovascular journal of Africa, 26(2 Suppl 1), S27-S38. doi:10.5830/CVJA-2015-038

26. Palstam, A., Sjödin, A., \& Sunnerhagen, K. S. (2019). Participation and autonomy five years after stroke: A longitudinal observational study. PLOS ONE, 14(7), e0219513.

27. Pan, A., Sun, Q., Okereke, O. I., Rexrode, K. M., \& Hu, F. B. (2011). Depression and risk of stroke morbidity and mortality: a meta-analysis and systematic review. JAMA, 306(11), 1241-1249.

28. Rhoda, A. (2012). Limitations in activity and participation experienced by stroke patients: A qualitative inquiry. South African Journal of Physiotherapy, 68(3), 20-24.

29. Rhoda, A., Cunningham, N., Azaria, S., \& Urimubenshi, G. (2015). Provision of inpatient rehabilitation and challenges experienced with participation post discharge: quantitative and qualitative inquiry of 
African stroke patients. BMC health services research, 15(1), 1-9.

30. Soeker, M. S., \& Olaoye, O. A. (2017). Exploring the experiences of rehabilitated stroke survivors and stakeholders with regard to returning to work in South-West Nigeria. Work, 57(4), 595-609.

31. Tricco, A. C., Lillie, E., Zarin, W., O'Brien, K. K., Colquhoun, H., Levac, D., . . Weeks, L. (2018). PRISMA extension for scoping reviews (PRISMA-ScR): checklist and explanation. Annals of internal medicine, 169(7), 467-473.

32. Urimubenshi, G. (2015). Activity limitations and participation restrictions experienced by people with stroke in Musanze district in Rwanda. African health sciences, 15(3), 917-924.

33. Vincent-Onabajo, G. O., Ihaza, L. O., Usman Ali, M., Ali Masta, M., Majidadi, R., Modu, A., \& Umeonwuka, C. (2016). Impact of social support on participation after stroke in Nigeria. Topics in Stroke Rehabilitation, 23(5), 305-310.

34. Wolfe, C. D. (2000). The impact of stroke. British medical bulletin, 56(2), 275-286.

35. The World Bank Annual Report 2003.

\section{Figures}




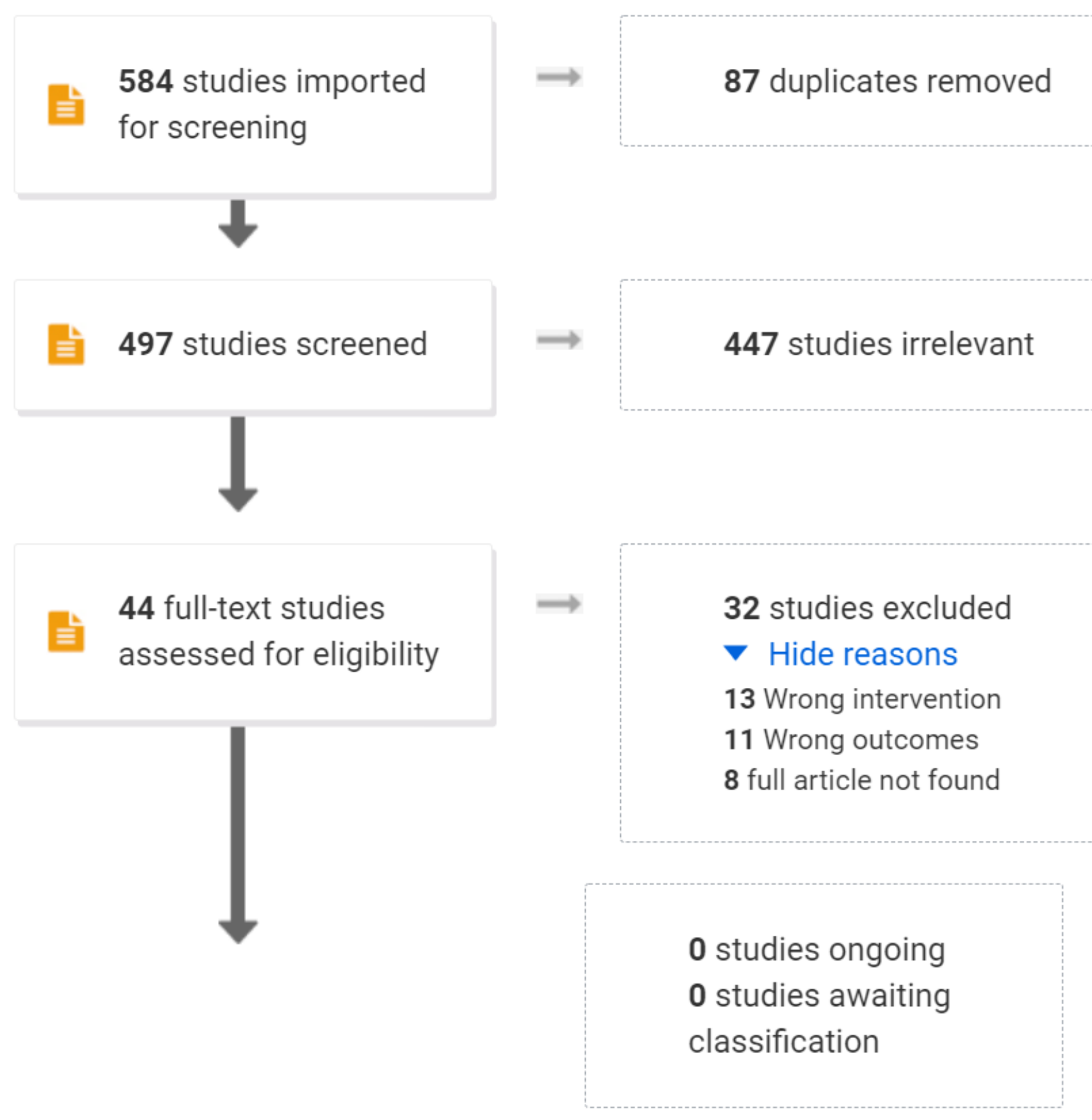

12 studies included

ing for api....

Figure 1

flow chart

\section{Supplementary Files}

This is a list of supplementary files associated with this preprint. Click to download. 
- Additionalfile1.docx

Page 19/19 